\title{
Adult-onset dystonia-parkinsonism
}

INSERM

\section{Source}

INSERM. (1999). Orphanet: an online rare disease and orphan drug data base. Adultonset dystonia-parkinsonism. ORPHA:199351

Adult-onset dystonia-parkinsonism is a rare neurodegenerative disease usually presenting before the age of 30 and which is characterized by dystonia, L-doparesponsive parkinsonism, pyramidal signs and rapid cognitive decline. 